\title{
Executive Open Selection, What's wrong?
}

\author{
Desy Mutia Ali \\ Faculty of Administration Science \\ University of Indonesia \\ Depok, West Java, 16424, Indonesia \\ desymutiaali@gmail.com
}

\author{
Eko Prasojo \\ Faculty of Administration Science \\ University of Indonesia \\ Depok, West Java, 16424, Indonesia \\ e_prasojo@yahoo.com
}

\author{
Lina Miftahul Jannah \\ Faculty of Computer Science \\ University of Indonesia \\ Depok, West Java, 16424 Indonesia \\ linamjannah@gmail.com
}

\begin{abstract}
The view of merit as a new basic system for public personnel management is already final in the newest regulation of ASN (National State Apparatus), and one kind of implementation of merit in the management system is recruitment and selection. Although the new regulation of public personnel management mandate the open competition for selecting top level position as promotion based merit, the question is, is the procedure already merit? Or is the competition itself already merit?This paper analyze the open selection a promotion based merit for JPT (Senior Executive Services/ Top Level Managerial/High Leader Position) in local government.
\end{abstract}

By using case studyon West Java Province and Depok City as the earliest province and city among the local governance who held the open competition system for JPT, the author hope this paper can give the real picture on the implementation of merit through the open selection system. The research objectives to see the implementation of merit in open competition model of JPT and obstacles of the process, analyze and criticize the procedure based on theory and the implementation. After analyzed the fact or real situation of the open competition procedure, this paper propose the better procedure or methods to be more merit and have the right decisions for promoting or hiring someone to be JPT.

Keywords: High Leader Position, merit system, open selection, civil servant

\section{INTRODUCTION}

In the era of rapidly changing organizational environments and politically dynamic, executive selection is even more critical than it was in the past. It also seems to be getting more difficult to do as performance demands are affected by multiple forces [1]. A few decades behind, no civil servant has a dream to be an executive manager (Echelon 2 or even Echelon 1) if they didn't know anyone in elite or unknown by elite from the institution. It just because they didn't have anybody to promote or sponsors them.
When the ASN established in 2014 and substitute the older one (UU 43, 1999) every ASN (National State Apparatus) has the same opportunities to join the competition or selection if they have the qualification.

Almost four years the ASN regulation established and merit system being based system on the public personnel management. Thoha (2016) said that "Good or not the system, it depends on who use the system, if the systems run by the good guys, ethics or morally good it will merit and have benefit for widely society. But, if it's lead by politician, habitually arranged by its political aspiration of the party"[2]. The Authority and political party were difficult to separate, and because of this, merit wouldn't run well. In both Europe and The United States, public personnel administrator has independence and differentiation from politics, but this condition did not represent the exclusion of administrators from making important contributions to policy or exerting political power[3]. In Indonesia, there's regulation that forbid the civil servant join the political party or being active in party, but interference from the politician as the authority in decision making couldn't avoid. The interaction between bureaucrat and politician were more intensive, especially in local government when the local political system change into direct election, based on policy regulation act No. 32/2004. Worse still, incumbent local government heads have undermined the neutrality of the local bureaucracy by filling important positions with handpicked political supporters. Consequently, discrimination in treatment occurs within the bureaucracy, which culminates into the promotion and demotion of personnel on the basis of affiliation rather than merit and capability [4].

In the promotion and demotion of the public officer, the highest decision maker usually called "PPK" such as ministerial, governor, or mayor is the politician and came from party. Every kind of decision in the public sector can be said that it's never be free or there's absolutely no political intervention. In the regional autonomy era, when the head of local government was selected by election, the political 
intervention were wider in all aspects of governance, no exception in selection, recruitment, or employee displacement. To control the objectivity of selection or recruitment process, there're some test or procedure being held by the institution, and it's usually called fit and proper test, assessment center, psychology test, computer assisted test, and etc.

The previous research by Nasir (2010) who investigates the reformation in recruitment system for Echelon II positions in Aceh government.The reformation process occupied the use of fit andproper test as a transparence and accountably processin selecting public servants. The selection process was also open for the public where every civil servantwith certain condition and gradecan participate. This way of selection process accommodates well the bestcandidates in fillingappropriate positions in Provincial Dinas. So far, the follow up of the selection processwas the performance evaluation which contains certain indicators[5]. In contrast, another research done by Herman (2012), and Kusharwanti (2008), practically merit and meritocracy couldn't run well in the selection, recruitment or promotion process because there're many things that should be concern first, for example there's no brave regulation state merit as a basic system for public personnel management; there's no commitment from the head of organization or top level management who made the highest decisions (Herman, 2012; Kusharwanti, 2008).

This paper focus on the merit implementation in open selection process. The research objectives to see the implementation of merit in open competition model of JPT and obstacles of the process, analyze and criticize the procedure based on theory and lesson learn from another country that already use this model. After analyzed the fact or real situation of the open competition procedure, we propose the better procedure or methods to be more merit and have the right decisions for promoting or hiring someone to be JPT.

\section{LITERATURE REVIEW}

Before analyze and criticize the open selection system in public personnel management, we introduce some framework that use in analyzing the data. Some merit concept, definition of selection high level officer/ executive level, and lesson learn from some country that already use selection system.

\section{A. Merit Concept}

Merit in selection practically have already done since hundreds of years, in China Dynasty. The recruitment of public officer firstly use in China[6]. This statement was taken by Kim from the article of Harvard Journal of Asiatic Studies about Chinas influence on the western examination system, which was written by Ssu-yu Teng, 1943. Teng suggest that China examination system were firstly known as a meritorious selection for public officer. According to Chinese classics, the Rites of Chou and the Book of Rites, the examination was held as early as 1115 B. C.[6].
Merit term in management has defined by many scientist into two categories, merit as an individual characteristics and merit as a system. Merit defined as an individual characteristics firstly promote by Young, 1961 in his book "The Rise of The Meritocracy". He re-conceptualize merit as sum of (I) Intelligence and (E) Effort, and symbolize I + E = $\mathrm{M}$, "Intelligence and effort together make up merit $(I+E=$ M). The lazy genius isnot one". [7]. According to Daniels, "Young imagines a word-wide society in the twenty-first century in which all assignments of jobs and rewards are based merit. The system is feasible because great advances in testing for intelligence and ability allow accurate great advances predictions of performance and permit appropriate educational tracking. All social barriers to the development of such abilities - social class, family background (but nor the family), race, and religion - are prevented from influencing decisions on education or career. Basic wages for different jobs are equal in order to avoid tiresome debates about the basis for inequalities in compensation. Nevertheless, vast inequalities of benefits and other rewards accompany jobs. These rewards are justified because they either provide incentives or insure efficient working conditions. Overall, rewards are proportional to merit. Merit is construed as ability plus effort. "'[8].

In line with Young, McNamee also define merit as an individual characteristic, he said that "...those who are most talented, the hardest working, and the most virtuous get and should get the most rewards."[9]. And Thompson (1995) define merit as value, he said that "which emphasizes that rewards ought to go to the most competent--those individuals with the best record of or potential for achievement"[10].

Another definition for merit as an individual was said by McCourt (2007). He said that "the best person" and "the appointment of the best person for any given job". This statement, "the best person" has some implication, such as applies to jobs at every level,the appointee is the best candidate, posts are open to all elgible candidates, and the appointment process is systematic, transparent and challengeable. Based on his definition, McCourt admitted that at least there're three obstacles for its restricted definition. First, it happened when merit is define as "able to do job", the nepotism could be done by the selection committee and their relatives. He argue that "It will be harder for a patron to insert a client into a job where knowledge and skill requirements are precisely specified than into one where they are left vague. This is a subtle butimportant point". Second obstacle is political patronage, where nepotism was represented by moral responsibility between 'daddy' and 'son". McCourt said that "a social altruist, discharging a noble obligation to politicalsupporters, family members and others". The third, the discrimination for irrelevant individual factors, such as race, role, religion, etc. So that, "appointment practices should be 'audited' to remove institutional discrimination"'[11].

In otherwise, some scientist, who classified merit as a system, was define merit in recruitment and selection 
context. Bernard Rosen (1975) in Woodard (2000) defined merit in a system of human resource management as a fairly and orderly process for hiring, paying, developing, promoting, retaining, disciplining, and retiring people on the basis of ability and performance.[12]. Kellough (2005), defined merit as a set of roles and procedure that use in the job fulfillment in civil servant [13]. And Stahl (1962) define merit wider in modern government, "a personnel system in which comparative merit or achievementgoverns each individual's selection and progress in the service and in which theconditions and rewards of performance contribute to competency and continuity ofthe service."[14].

Table 1. Summary of Previous Research

\begin{tabular}{|c|c|c|c|c|}
\hline No & $\begin{array}{l}\text { Researcher/ } \\
\text { Year/ } \\
\text { Topic }\end{array}$ & $\begin{array}{c}\text { Focus } \\
\text { research/Objective }\end{array}$ & Method & Result \\
\hline 1. & $\begin{array}{l}\text { Woodard } \\
\text { (2000) } \\
\text { Merit in } \\
\text { Principle, Merit } \\
\text { in Practice: An } \\
\text { Investigation } \\
\text { into Merit- } \\
\text { Based Human } \\
\text { Resources } \\
\text { Management } \\
\text { Through the } \\
\text { Lens of Title 5- } \\
\text { exempt } \\
\text { Organizations }\end{array}$ & $\begin{array}{l}\text { Merit principle } \\
\text { implementation }\end{array}$ & $\begin{array}{l}\text { Survey, } \\
\text { note, by } \\
\text { phone or } \\
\text { interview }\end{array}$ & $\begin{array}{l}\text { The basic } \\
\text { element of } \\
\text { merit and its } \\
\text { value, such } \\
\text { as } \\
\text { fairness and } \\
\text { equity, } \\
\text { competitive } \\
\text { hiring and } \\
\text { promotions, } \\
\text { equality } \\
\text { based } \\
\text { compensatio } \\
n \quad \text { schemes } \\
\text { due process. }\end{array}$ \\
\hline 2. & $\begin{array}{l}\text { Halim (2002) } \\
\text { Kebijakan } \\
\text { Promosi } \\
\text { Jabatan di } \\
\text { Birokrasi } \\
\text { Tingkat Lokal }\end{array}$ & $\begin{array}{l}\text { merit system } \\
\text { implementation in } \\
\text { promotion policy in } \\
\text { local governance } \\
\text { and factors }\end{array}$ & $\begin{array}{l}\text { Qualitati } \\
\text { ve } \\
\text { descripti } \\
\text { ve }\end{array}$ & $\begin{array}{l}\text { The result } \\
\text { shows that in } \\
\text { general the } \\
\text { promotion } \\
\text { policy in } \\
\text { local } \\
\text { government } \\
\text { is un merit. }\end{array}$ \\
\hline 3. & $\begin{array}{l}\text { Anirudh and } \\
\text { Pedro (2003) } \\
\text { What Lies } \\
\text { Beneath: } \\
\text { Political Roots } \\
\text { of State Merits } \\
\text { Systems. }\end{array}$ & $\begin{array}{l}\text { Research the } \\
\text { reasons from some } \\
\text { country who adopt } \\
\text { merit system in the } \\
\text { beginning of twenty } \\
\text { century, and some } \\
\text { of federal country. }\end{array}$ & $\begin{array}{l}\text { Empirica } \\
1 \text { study }\end{array}$ & $\begin{array}{l}\text { According to } \\
\text { the analyze, } \\
\text { merit was } \\
\text { adopt at } \\
1900-1939 .\end{array}$ \\
\hline 4. & $\begin{array}{l}\text { Colley (2006) } \\
\text { Aprouches to } \\
\text { the Merit } \\
\text { Principle in } \\
\text { Quesland } \\
\text { Public Service } \\
\text { Recruitmen } \\
1959-2000\end{array}$ & $\begin{array}{l}\text { Merit perspective in } \\
\text { public personnel } \\
\text { career system in } \\
\text { Queensland }\end{array}$ & $\begin{array}{l}\text { Qualitati } \\
\text { ve } \\
\text { method }\end{array}$ & $\begin{array}{l}\text { Merit was } \\
\text { ignored in } \\
\text { public } \\
\text { personnel } \\
\text { management } \\
\text { career } \\
\text { system, it } \\
\text { impact to the } \\
\text { ability and } \\
\text { the quality } \\
\text { of public } \\
\text { worker. }\end{array}$ \\
\hline
\end{tabular}

\begin{tabular}{|c|c|c|c|c|}
\hline 5 & $\begin{array}{l}\text { Medelina } \\
\text { Kusharwanti } \\
(2008) \\
\text { "Analisis } \\
\text { Kebijakan } \\
\text { Rekrutmen dan } \\
\text { Seleksi Pegawai } \\
\text { Negeri Sipil di } \\
\text { Indonesia" }\end{array}$ & $\begin{array}{l}\text { Find the root } \\
\text { problem and the } \\
\text { main cause the } \\
\text { weakness of merit } \\
\text { enforcement }\end{array}$ & $\begin{array}{l}\text { Qualitati } \\
\text { ve } \\
\text { method } \\
\text { with } \\
\text { scenario } \\
\text { planning }\end{array}$ & $\begin{array}{l}\text { The result } \\
\text { shows, } \\
\text { recruitment } \\
\text { policy were } \\
\text { faced strong } \\
\text { political } \\
\text { interfere, } \\
\text { and lowness } \\
\text { of elite } \\
\text { commitment } \\
\text {; vague } \\
\text { distribution } \\
\text { of authority } \\
\text { between } \\
\text { institution, } \\
\text { and there's } \\
\text { no synchronize } \\
\text { macro and } \\
\text { micro } \\
\text { policy. }\end{array}$ \\
\hline 6 & $\begin{array}{l}\text { Herman } \\
\text { (2012)“Meritok } \\
\text { rasi Dalam } \\
\text { Pengisian } \\
\text { Jabatan } \\
\text { Pegawai Negeri } \\
\text { Sipil di } \\
\text { Indonesia” }\end{array}$ & $\begin{array}{l}\text { Implementation of } \\
\text { meritocracy in job } \\
\text { fulfillment, the } \\
\text { obstacles and the } \\
\text { strategy to } \\
\text { implement it } \\
\text { effectively. }\end{array}$ & $\begin{array}{l}\text { Qualitati } \\
\text { ve } \\
\text { method }\end{array}$ & $\begin{array}{l}\text { The job } \\
\text { fulfillment in } \\
\text { three case } \\
\text { were not } \\
\text { merit yet. }\end{array}$ \\
\hline 7 & $\begin{array}{l}\text { Makhdum } \\
\text { Priyatno, 2013, } \\
\text { Rekonseptualisa } \\
\text { si Merotokrasi } \\
\text { dalam } \\
\text { Penempatan } \\
\text { Pejabat di } \\
\text { Negara } \\
\text { Kesatuan RI; } \\
\text { Aplikasi SSM- } \\
\text { Based Action } \\
\text { Research } \\
\text { Dalam Tiga } \\
\text { Level } \\
\text { Kelembagaan }\end{array}$ & $\begin{array}{l}\text { Meritocracy from } \\
\text { three level } \\
\text { institutional } \\
\text { perspective }\end{array}$ & $\begin{array}{l}\text { SSM- } \\
\text { Based } \\
\text { Action } \\
\text { Reaseac } \\
h\end{array}$ & $\begin{array}{l}\text { In macro } \\
\text { level, } \\
\text { meritocracy } \\
\text { should be } \\
\text { stated in } \\
\text { policy about } \\
\text { public } \\
\text { personnel } \\
\text { management } \\
\text { In meso-1 } \\
\text { level, } \\
\text { coordination } \\
\text { in strategic } \\
\text { level; } \\
\text { meso-2 in } \\
\text { level, } \\
\text { training and } \\
\text { education for } \\
\text { apparatus } \\
\text { should be } \\
\text { based on } \\
\text { competence; } \\
\text { In micro } \\
\text { level, find } \\
\text { and placement } \\
\text { the talented } \\
\text { officer. }\end{array}$ \\
\hline
\end{tabular}




\begin{tabular}{|c|c|c|c|c|}
\hline 8 & $\begin{array}{l}\text { Endah } \\
\text { Setyowati } \\
(2014) \\
\text { Analisis Merit } \\
\text { System dalam } \\
\text { Proses } \\
\text { Rekrutmen Dan } \\
\text { Seleksi CPNS } \\
\text { di Kota Malang } \\
\text { (Pelaksanaan } \\
\text { Rekrutmen dan } \\
\text { Seleksi CPNS } \\
\text { Tahun 2010). }\end{array}$ & $\begin{array}{l}\text { Analyze obstacles } \\
\text { to implement merit } \\
\text { principle in the } \\
\text { recruitment process } \\
\text { of CPNS }\end{array}$ & $\begin{array}{l}\text { Qualitati } \\
\text { ve } \\
\text { method }\end{array}$ & $\begin{array}{l}\text { The result } \\
\text { found that } \\
\text { recruitment } \\
\text { process of } \\
\text { CPNS in } \\
\text { Malang City } \\
\text { was not } \\
\text { merit yet. } \\
\text { There're } \\
\text { indication of } \\
\text { corruption, } \\
\text { and } \\
\text { nepotism. }\end{array}$ \\
\hline
\end{tabular}

In this paper, the author define merit as a system of selection, asa fairly and orderly process on the basis of ability (competency) and performance.

\section{B. Executive Selection (High Leader Positio, 'JPT')}

Before we discuss about the promotion model, it's better to know who the executive. Silzer's (2002) categorize the executive as general managers, corporate officers, and heads of major organizational functions and business units (Silzer, 2002). In the private sector it's known as CEO, whereas the public sector usually called Senior Executive Services in some countries, such as United States, England, Filipina, and etc. In Indonesia, since the ASN regulation established, high level position for public services is called Jabatan Pimpinan Tinggi (JPT).

The functions of public personnel management are procurement and allocation. Procurement is advertise, recruit, and select labor; while allocation is promote and transferred (Klingner \& Nalbandian, 1985). Promote and transfer is a part of placement function, beside demotion and job posting programs. And recruitment concept, selection and promotion becoming the one topic, which is called "process and skills: from start to finish".

For the selection theory, Vinkenburg, et al (2014) in the journals of group \& organization management divided the theoretical model of promotion into two big model, upward mobility system and tournament theory. In the mobility system, there are contest vs sponsored mobility and another one is tournament system. Contest mobility refers to an open market for top position, where candidate are continuously screened and where performance determines success (Turner, 1960 in Vinkenburg, 2014). Versus type of contest is sponsored, it refers to a closed market for the top position, with early screening for potential (and thus elite creation) and where the origin and background determine success. Because speed of advancement accelerates for the chosen few, the selection of candidate for top management position occurs quite early in the career. Sponsors are members of the dominant elite (typically top managers themselves), who use their influence to advocate for candidates and actively create career opportunities for them[15][16]. A historical model in contrast, are path of independence. Rosenbaum (1979) a historical model, which advancing to the top, is modeled as taking a part in a tournament, where candidates compete continuously for promotion[17] .

\section{METHODS}

This research uses qualitative method, and data collection uses literate review and interview method. For getting an accuracy data, the interviewees are chosen because of the intensity of engagement with the policy and knowledge about open selection policy, such as the policy makers from Ministry of Empowerment of Civil State Apparatus and Bureaucratic Reform (KEMENPAN-RB) and academic experts in policy making and public administration. In this case, the paper focuses on JPT Pratama for the head of Departmen or 'Kepala Dinas' and JPT Madya for Regional Secretary. For regional or local government there's no JPT Utama, because it is just for central government. Table 1 will summarize the subject of this research. The data interview and document is analyzed with content analysis system. Content analysis is a systematic approach of coding and classification to determine trends, relation, pattern structure and frequency of the word from a text (M. Vaismoradi, H. Turunen, and T. Bondas , 2013). While, Y. Darlington and D. Scott (2002) stated that content analysis is process to identify specific characteristic from content by exploring verbal, visual, behavior, pattern and themes.

It will be a list of keywords that found in the interview, and clustering these findings into determinants or factors that are defined from the theory.

Table 2. Subject Research

\begin{tabular}{|c|l|c|}
\hline No & \multicolumn{1}{|c|}{ Subject Capacity } & Amount \\
\hline 1 & $\begin{array}{l}\text { HRM Deputy from Ministry of Empowerment of Civil } \\
\text { Services Apparatus }\end{array}$ & 1 \\
\hline 2 & The Member of Civil State Apparatus Commission & 2 \\
\hline 3 & The Academic Experts & 2 \\
\hline 4 & The selection committee & 2 \\
\hline 5 & The secretariat of selection & 2 \\
\hline 6 & The candidates & 5 \\
\hline
\end{tabular}

Data analyzes of merit in process and content on the open selection system that has been done by West Java Government Province, came from an interview with the selection committee, participants, and the organizers for two years periode 2014 until 2015. There are five open selection cases that we analyze, open selection for the head of department education, the head of Knowledge and Technology, the head of Organization Bureau, the head of Development Administration and Regional Secretary position.

\section{RESULT AND DISCUSSION}

To answer the research questions about how local government implement of open selection based merit policy, the data collection began with collecting the documents, such as the policies, and activities report. Second step is interview with subjects, from KASN and policy maker (Deputy of Human Resource of Ministry of Empowerment of Civil Service Apparatus. The data collecting began at February to August, 2016 for West Java Province, and February to March, 2017 for Depok City. The research began collecting 
the data from Civil State Apparatus Commission in January December, 2016 by interviewing the Head and member of commission. The table below describes the amount of institution which already process or held the open selection system since 2014 to 2016.

Table 3. The Status of Open Selection for Senior Executive Officer (JPT)*

\begin{tabular}{|c|l|c|c|c|c|}
\hline No & \multicolumn{1}{|c|}{ Status } & Ministerial & $\begin{array}{c}\text { Non } \\
\text { Ministerial }\end{array}$ & Province & $\begin{array}{c}\text { Distict/ } \\
\text { city }\end{array}$ \\
\hline 1 & Finish & 32 & 25 & 21 & 247 \\
\hline 2 & Process & 2 & 14 & 9 & 127 \\
\hline 3 & Consultation & 0 & 3 & 2 & 59 \\
\hline 4 & Not yet & 0 & 0 & 2 & 75 \\
\hline 5 & Complaint & 5 & 1 & & 40 \\
\hline
\end{tabular}

*Source: Civil Service Apparatus Commission, the data valid until Desember 2016

The research in West Java Province and Depok City begin with collecting the open selection document or report of the activities. For West Java, there are five reports of open selection activities, there are open selection for General Secretary, Head Department of Education, Head of Department of BP3IPTEK, Bureau Chief of Organization, and Bureau Chief of Development Administration. In Depok City, two reports collect for open selection activities, there are General Secretary and Head Department of Natural Resource \&Water.

The open selection activities are managed by Local Employment Agency ("Badan Kepegawaian Daerah"), and directed manage by division of Employement Development, sub division of employee mutation. However, for each activity, there is a team for secretariat which is focus on managing all process of the activity from selecting the selection committee to final report. The data collection, resume in table 3 .

Table 4. Issue of Findings

\begin{tabular}{|c|c|c|c|c|c|}
\hline \multirow[t]{2}{*}{ No } & \multirow{2}{*}{$\begin{array}{c}\text { Step/ } \\
\text { Process }\end{array}$} & \multicolumn{2}{|c|}{ Findings of issues } & \multirow{2}{*}{$\begin{array}{c}\text { Cluster } \\
\text { of Issues }\end{array}$} & \multirow{2}{*}{$\begin{array}{c}\text { Sum } \\
\text { of } \\
\text { Issues }\end{array}$} \\
\hline & & West Java & Depok & & \\
\hline 1 & Preparation & $\begin{array}{l}\text { Coordination } \\
\text { with the } \\
\text { vertical } \\
\text { institution, } \\
\text { selecting } \\
\text { person for } \\
\text { selection } \\
\text { committee }\end{array}$ & $\begin{array}{l}\text { Choosing } \\
\text { proffesional } \\
\text { and experties to } \\
\text { become the } \\
\text { selection } \\
\text { committee, the } \\
\text { understanding } \\
\text { of the employee } \\
\text { about the open } \\
\text { selection } \\
\text { system }\end{array}$ & fairness & 4 \\
\hline 2 & Execution & $\begin{array}{l}\text { Participant,s } \\
\text { election, } \\
\text { qualification, } \\
\text { competency, } \\
\text { assessment } \\
\text { center, }\end{array}$ & $\begin{array}{l}\text { Participants, } \\
\text { selection, time } \\
\text { for registration, } \\
\text { qualification, } \\
\text { tools } \\
\text { (assessment } \\
\text { center), } \\
\text { competency, } \\
\text { Budget, }\end{array}$ & $\begin{array}{l}\text { Competit } \\
\text { iveness, } \\
\text { fairness, } \\
\text { openess }\end{array}$ & 10 \\
\hline 3 & Result & $\begin{array}{l}\text { The openess } \\
\text { of the result }\end{array}$ & $\begin{array}{lr}\text { Fairness, } & \text { final } \\
\text { decisions } & \text { of } \\
\text { PPK } & \end{array}$ & Fairness, & 5 \\
\hline
\end{tabular}

The table describe the issues that usually find in the interview with the interviewees. The issues are clustering into some criteria of the merit principless such as fairness, competitiveness, and openess. Based on interview result, it analyze the data into three domain in open bidding and codes by its domain, such as PF (Process Fair), PO (process open), PC (process competitive); $\mathrm{CF}$ (content fair), $\mathrm{CO}$ (contain open), CC (content competitive); and RF (result fair), RO (result open), RC (result competitive). Figure 1, shows that Result Open (RO), Result Fair (RF) and Content Fair (CF) come more frequently than others. It means that many respondents have higher attention on the openness of the result. Some of them said that they're satisfied enough with the system, even the announcement just tell about three person who has passed all test brightly and having the highest scores from others candidate. The openness also has connection with the fairness.

According to Regional Employee Board of West Java Province from Indonesian Civil Servant State Statistical Indexbetween 2007-2014, the amount of the ASN is 13.291 civil servant and becoming the third largest amount of civil servant in Indonesia. This amount spread into three prosition, 8.414 civil servant for non structural, structural position in 1.464 , and 3.413 for specific functional. It can be seen as this figure below.

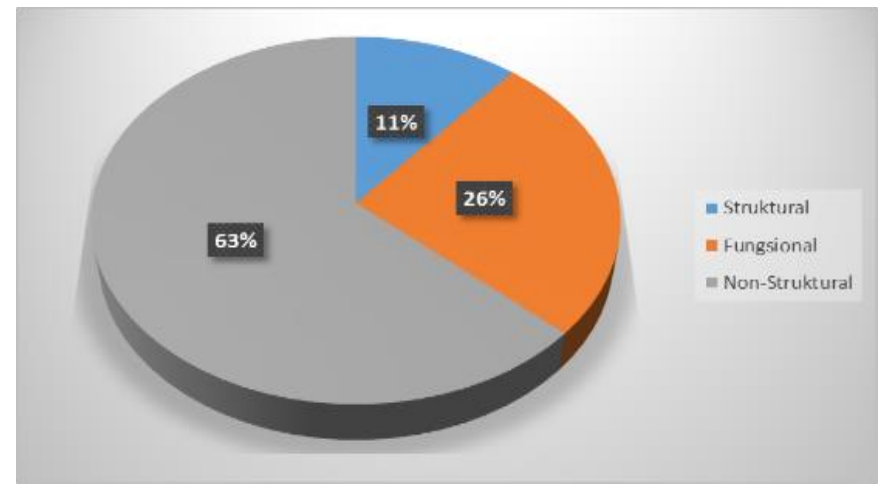

Figure 1. The Distribution of West Java Province civil servant based on position

Source: Regional Employee Board of West Java Province

Specify on structural position, the data collection per Januari 2016 can be seen in this figure bellow: 
Picture 2. Distribution of civil servant based on structural position

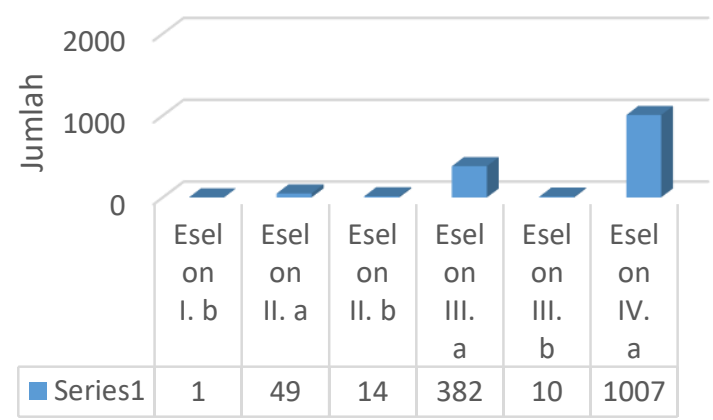

Source: Regional Employee Board of West Java Province

Based on the ASN regulation nomenclature of echelon is canged into some term, supervisor for echelon 4, administrator for echelon 3, JPT Pratama for echelon 2, JPT Madya for echelon 1 and the top manager/head institution besides Ministery become JPT Utama. In this case, the paper focus on JPT Pratama for the head of Departmen or 'Kepala Dinas' and JPT Madya for Regional Secretary. For regional or local government there's no JPT Utama, because it just for central government.

\section{A. The voyage of JPT selection model}

Before we discuss about the promotion model, it's better to know who the executive. Silzer's (2002) categorize the executive as general managers, corporate officers, and heads of major organizational functions and businessunits[18]. In the private sector it's known as CEO, whereas the public sector usually called Senior Executive Services in some countries, such as United States, England, Filipina, and etc. In Indonesia, since the ASN regulation established, high level position for public services is called Jabatan Pimpinan Tinggi (JPT).

To answer the research question, we better know the voyage of selection system/model in Indonesia since the regulation of public personnel management established. From the data and regulation review, the process to implement merit as a system in promotion system of civil servant in bureaucracy has three phase, there are:

\section{B. Colleague gift}

The first phase of promotion model in personnel management can be called as "promotion gift". At the time, becoming the civil servant like a 'gift' of independence. New government just built the system, recruit the civil servant in sheaves. Unfortunately in this phase patronage and spoils system were commonly used to recruit civil servant. If someone has graduation from junior or senior high school and has ability to do a simple job, such as typing or writing, and has a family that's already be a civil servant, he/she could be PNS. In this phase, government made a policy or act to manage the PNS which is called UU 8, 1974 about the personnel issues or the principle of public personnel management. In this act, every PNS could get the higher level regularly every four years. Indonesia, according to UU 8, 1974 management system in this phase adhere the combination the career and merit system [19]. There was no need special requirement to get promotion into the higher rank, it's just administrative requirements, DP3 assessment result, proposal subjectively from the boss or the higher officer. The advantages of the system was every employee has the same opportunity to promote regularly. In another, the disadvantages, this system was not merit yet, because there're no competition, job performance or achievement to have the promotion.

For another promotion system, such as promote in the higher position which's called 'echelon', merit was already tried to be the consideration. Merit in this act use DP3 assessment, ability, experience and interest, but it was locked with list of rank order (Daftar Urutan Kepangkatan) and other objective criteria such as loyalty, and trusted. The rule said, "Pengangkatan Pegawai Negeri Sipil dalam suatu jabatan dilaksanakan dengan memperhatikan jenjang pangkat yang ditetapkan dalam jabatan itu."(17 clause (2), UU 8/1974). Nevertheless, the objective consideration were stated in clause 19 and 20, it stated, "Pengangkatan dalam jabatan didasarkan atas prestasi kerja, disiplin kerja, kesetiaan, pengabdian, pengalaman, dapat dipercaya, serta syarat-syarat objektif lainnya." (19 clause, UU No.8/1974)[20].

List of work assessment (it's called DP3 than) that was intended in 20 clause, were explained in Government Regulation no. 10, 1952[21]. DP3 was the work assessment of an employee in one year, which's made by direct higher official. The element to be assessed were loyalty, job performance, responsibility, adherence, honesty, teamwork, initiative and leadership. Unfortunately, the guidance to assess these element was not clear and multi interpretation, so it's still subjective. The promotion process was becoming subjective and un-merit when there's colleague known there. At the time, even if someone has already their time in DUK to promote there would not chance for him/her if they're not promote by their boss (higher official). In this case, every subordinates should have good relation to the boss and well known. This condition happen almost in all institution, and it's getting worse in local governance. Merit spirit was vague with the patronage and spoils system.

\section{Selective Logging}

Reformation event at 1998 brought the wider change in all government areas, not only politic, and economy, but also bureaucracy system. The public personnel issues constitution was not accordance with the condition at that time, and it requires adjustment. In this phase, the regulation was chance from UU 8, 1974 to UU 43, 1999. This regulation was not 
totally change, it just modified some clause for adjustment to the situation demand.

In this phase, civil servant merit promotion system was more required strict, because there're competency as one of requirement to be promoted. Based on Government Regulation (PP) no.10, 2000, civil servant whose was promoted as structural level should be appointed by the professional principle, such as competency, job performance, and the level of rank assigned for the position, and other objective requirements without any discrimination for gender, ethnic, religion, race and group society (PP 10,2000). in two years later, the regulation was modified and there're more objective requirement in eight required, such as (1) education: basic and general education, (2) in job training and education (diklat); (3) years of services; (4) rank and class; (5) late position; (6) assessment result (DP3); (7) Lis of DUK; (8) competency and job performance.

Another element that added in this regulation was the formation of internal assessment team, which's called BAPERJAKAT. According to the selection model theory, this phase use traditional model or sponsor. The sponsors or the member of BAPERJAKAT was dominant with the elite organizations or top level management, but there're leveling of BAPERJAKAT itself, such as Baperjakat in a middle level (for echelon $3 \& 4$ ) and top level (for echelon 1 \& 2).

\section{Open Competition}

The phase of open competition is newest model in promotion system of civil servant in Indonesia. Open competition model is a mandate of ASN Act or UU 5, 2014. The regulation is totally chance the public servant management, which's based on merit system. In the phase, the empty position of top level management (Jabatan Pimpinan Tinggi (JPT)) is announced by the institution and every employee who has the same qualification to the position can join the competition to be the candidate. In the last phase, Civil Service Commission (KASN) was established to watch merit system implementation. Based on the theory of selection model [16], this promotion model is kind of tournament or contest, where every candidate has to passed every step/test. It process usually known as "beauty contest". Every contest, the institution should create the PANSEL or judges who give the score for each stage of the contest and give the final score as the result of all stages of the contest to the PPK or person who make the decision for the selection in the top level management (i.e. President, Minister, or Governor). The open competition system is the screening series by using many methods such as document review, writing test, assessment center, medical checkup, and interview by panel.

This paper is focus on the last phase of promotion model above, open competition. Analyzing merit basically is the existence of the merit principle, fairness, competitiveness, and openness in a set of selection process and the content of test. Data analyzes of merit in process and content on the open selection system that has been done by West Java
Government Province, is came from interview with the selection committee, participants, and the organizers for two years periode 2014 until 2015. There are five case open selection that we analyze, open selection for the head of department education, the head of Knowledge and Technology, the head of Organization Bureau, the head of Development Administration and Regional Secretary positions.

Based on the new regulation ASN, know we are in the open competition phase, whereas merit become the best system to implement in employee management special in selection or promotion. The picture bellow explain the schema of the promotion based merit (Open Competition Model) based on Ministerial Regulation No. 13, 2014.

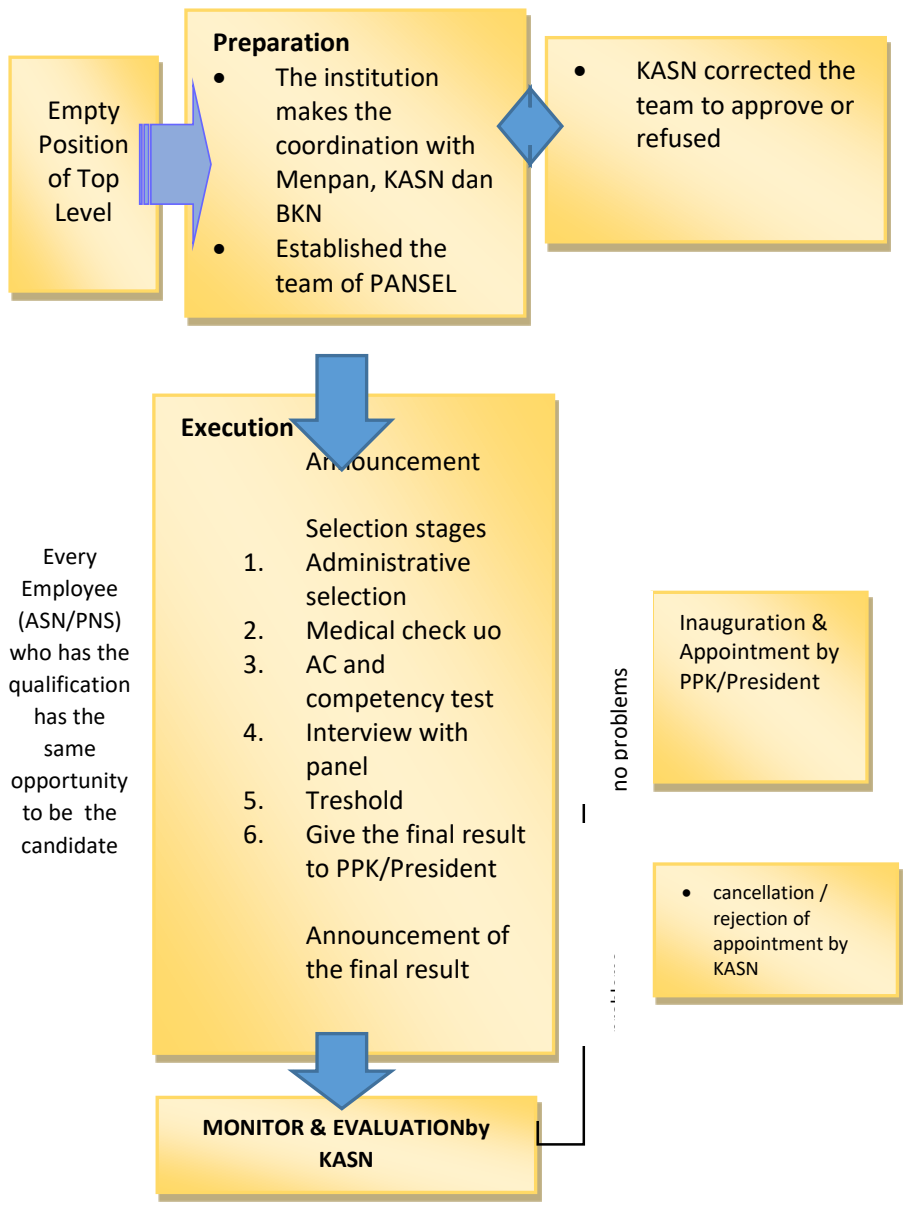

Fig. 3. The schema of the promotion/selection process based on Ministerial Regulation no. 13, 2014 and UU No. 5, 2015. [22]

By doing the content analyzes of interview transcript, the reality of the process can be described as follows:

\section{A. Preparation Phase}

In this phase the activity should be merit. The organizers of open competition in West Java Province which is conducted by regional employment agency, coordinated with KASN (State Apparatus Commission), and BKN(National Civil Service Agency). The content of coordination is about 
regulation of open selection and how to build steering committee. In this phase, organizers must be sure about the process, including time schedule, activities and person involves already in accordance with the regulation.

The open selection is managed by the Regional Employment Board under the field of Employee Development, and sub-field of Employee Mutation. However, for each activity (open selection for one position) it's managed by a secretary team that is made for one selection, focused on it from the beginning until the end of the process.

Merit for this phase is about how to design the orderly process and the commitment of the authority to make the process based on merit, as it state in regulation. The obstacles that potentially faced in this phase are: the capacity of the people in the regional employee board to understand and simplify the law or regulation, there's no communication or less coordination between the employee manager and central institution such as NCSA (BKN), KASN, and The Minister of State Civil Apparatus (KemenPAN-RB). In West Java Province, there's good relation and communication to the central institution that manage the civil servant. The officials in Regional Employee Board were quick response with the new regulation. So it can be said that there's no potential obstacles in this phase for West Java Province to arrange the open selection for JPT.

\section{B. The Execution Phase}

In this phase, the activity, and the content should be merit. The activities include for this term are announcement, administrative selection, paper selection, medical check-up, assessment center, and the last, panel interview by the committee. The merit principle must be in this term are fairly process, open, orderly process, confidential result, and valid and reliable of the test. Every candidate get the same process and there's no different process between internal or external candidate.

Even though West Java Province one of the earliest province that use thin model for selection but over all they can manage the event correctly and no complaint (Mokhsen, 2015). All event were announced by the online media (official website of West Java Province for Open Selection, www.seleksiterbuka.jabarprov.go.id), and also official letter for Internal Department, and specific for Regional Secretary it was also announced on National Newspaper (Harian Umum Pikiran Rakyat edisi 19 Mei 2015).

Obstacles that potentially faced in this phase by organizers are: (1)Minim participant, there's no civil servant who wants join the competition, or it just few persons that registered to the program. There are some causes why the program has fewer candidate to register, first, belief system or culture. Some people belief that self-promotion is forbidden because its mean arrogant, and being the candidate by self-register to the contest has same meaning with selfpromotion. This kind of beliefs many found in Sundanese and Javanese society. Second, poor of trust, one of reason why ASN didn't want to join the open selection in local government is because there're poor of trust to the highest decision maker, i.e. mayor, regent, or governor incumbent. People already knows by rumors or common opinion whose person will be the chosen candidate, and the selection result become subjective and un-merit. (2) Poor coordination, other obstacles can be faced by the local/regional institution that's far from the central government. Poor coordination could make misperception or misinterpretation about the law or regulation. There're many local government institution which run the open selection without coordination with KASN, the result of open selection was refused or rejected the appointment by KASN. (3) Level capacity of the local government, capacity include of facilities, level understanding of the ASN about the rules or regulation that is used to run the program, and regional finance. (4) Poor commitment of district head (Bupati, Mayor, and Governor) to run selection by merit. Some of incumbent wants their authority saved, so they have to design their apparatus by their followers, and some of them were not competence at all. This system is just like the patronage and spoils. (5) The political pressure of incumbent. Even though bureaucracy is separate with the politics, and it's have to be neutral, but practically it's hard to control this, because its happened not only in the local government but also in central government. This political pressures are bigger for strategic position in bureaucracy, such as Regional Secretary, Head Department of Education, Head Department of Health and Head Department of General Work in regional government; and in the central institution strategic positions are usually for top level or JPT Utama and Madya.

The last stage is monitoring and evaluating phase. Controlling merit implementation, KASN make the rules and guidance to monitor and evaluate the system. KASN has the authority to cancel or reject the selection result and pending the inauguration. For JPT Madya\&Utama, KASN has to meet the President and report its evaluation about the process to give the President consideration. KASN has to make sure the process and the content of open selection already based merit.

After analyze the process, the author analyze the content of merit implementation in the open selection system. By analyzing the content and process, we can describe what should be or not to be done in each phase. Based on analyze merit by content, there're some notes that potentially broke the merit. The notes are: (1) there're no specific competency for each position announced in qualification; (2) there's no committee standardization for ability or judgment and certification; (3) there's no standardization the Assessment Center institutions or organizers; (4) there's just administrative judgment for judge the loyalty and honesty, whereas it's still difficult to judge this area in short time.

\section{CONCLUSION}

Open selection system in promoting apparatus is one kind of bureaucratic reform. Now, for some years maybe it becomes the best system to produce bureaucracy more professional, and merit. In process, there are many obstacles 
that is faced in the system, it can be from the regulation itself, the understanding of human resource as bureaucrat whose run the system, commitment of the leader to make decision based on merit, and etc. However, to be merit or adapting merit in Indonesia bureaucracy need any justification because there are so many blockage that faced in the process of open selection model. The kind of blockage can be structure, culture, or political system. The blockage can make the merit system unsuccessful, and it needs strategies to overcome the problems. The result of this research suggest the strategies in every part of the systems, such as institutional, the regulations, and the political system.

\section{References}

[1] Valerie I. Sessa, Robert Keiser, Jodi K.Taylor, and Richard J. Campbell, Executive Selection: A Research Report on What Works and What Doesn't. Greensboro, North Carolina: Center of Creative Leadership, 1998.

[2] Miftah Thoha, "Meritokrasi Jabatan dan Parpol," Opini Kompas, Juni 2016.

[3] James H. Svara, "Leadership by Top Administrators in a changing world," in Transforming Public Leadership for the 21st Century. London: M.E. Sharpe, 2007, pp. 69-102.

[4] Edison, "Meritokrasi VS Politisasi Jabatan Karir Dalam Birokrasi Lokal: Sebuah Paradoks Netralitas Birokrasi," Jurnal Kebijakan dan Administrasi Publik UGM Vol.16 No. 1, pp. 67-76, Mei 2011.

[5] Muhammad Nasir, "REFORMASI SISTEM REKRUTMEN PEJABAT DALAM BIROKRASI PEMERINTAH: (STUDI KASUS REKRUTMEN PEJABAT ESELON II DI PROVINSI NANGGROE ACEH DARUSSALAM)," Jurnal Kebijakan dan Manajemen PNS, 2009.

[6] Jong Bok Kim, Implementation of Western Concept of Merit in Developing Society: The Case of Korean Civil Service System, University of Geeorgia, Athena, 1978.

[7] Michelle Young, The Rise of The Meritocracy. Mitcham, Victoria: Penguin books, 1961.

[8] Norman Daniels, "“Merit and Meritocracy"," Philosophy \& Public Affairs, 7, No.3, p. 207, 1978.

[9] Stephen J. McNamee, The Meritocracy Myth. New York: Rowman \& Littlefield Publishers., 2004.

[10] Frank J. Thompson, "The politics of public personnel administration. ," in Public personnel administration. Problems and prospects. New York: Prentice Hall, 1995.

[11] Willy McCourt, "“The Merit System and Integrity in the Public Service"," in Conference on Public Integrity and Anticorruption in the Public Service, Bucharest, 29-30 May. 2007, p. p.2.
[12] Collen A Woodard, "Merit in Principle, Merit in Practice-An Investigation into Merit-based Human Resources Management," Virginia, 2000.

[13] J. Edward Kellough, "Reinventing Public Personnel Management: Ethical Implementation for Managers and Public Personnel System," Public Personnel Management, p. 655, 1999.

[14] Glenn. O. Stahl, Public Personnel Administration. London: Harper \& Row, 1962.

[15] H., Carter, N.M., \& Silva, C. Ibarra, "Why men still get more promotions than women," Harvard Business Review 88(9), pp. 80-126, 2010.

[16] Claartje J., Jansen, Paul G. W., Dries, Nicky, Papermans, Roland Vinkenburg, "Arena: A critical conceptual framework of Top Management Selection," Group \& Organization Management, pp. 33-68, 2014.

[17] M., \& Severinov, S. Schwarz, "Investment Tournament: When should a rational agent pull all eggs in one basket?," Journal of Labour Economics, 28, pp. 893922, 2010.

[18] R. (2002). Preface. In, Silzer, "Preface," in The 21st century executive: Innovative practices for building leadership at the top.. San Francisco: Jossey-Bass, 2002.

[19] CSC, "Compendium of ASEAN Civil Service System," in ASIAN Conference on Civil Service Metter, 8th, Bangkok, Thailand, 1995.

[20] UU, Undang-undang 8, 1974.

[21] PP, PP 10, 1952.

[22] Ministerial Regulation, Permenpan 13, 2014.

[23] Medelina Kusharwanti, "Analisis Kebijakan Rekrutmen dan Seleksi PNS di Indonesia," Depok, 2008.

[24] Herman, "Meritokrasi dalam Pengisian Jabatan Pegawai Negeri Sipil di Indonesia," Depok, 2012. 